\title{
Potash regime for restoration of disturbed lands in the Far North
}

\author{
Anatoly Iglovikov ${ }^{1,2, *}$ \\ ${ }^{1}$ Northern Trans-Ural State Agricultural University, Tyumen, 7, Republic street, 625003, Russia \\ ${ }^{2}$ Tyumen Scientific Centre SB RAS, Tyumen, 86, Malygina street, 625026, Russia
}

\begin{abstract}
Disturbed soils of the Far North, underlain by permafrost, have extremely low fertility and were formed according to natural and climatic conditions. These soils and the vegetation cover formed on them are very vulnerable to destructive anthropogenic impacts associated with the industrial development of the North. To restore vegetation cover, agrotechnical techniques are used, including the use of various fertilizers. This article will address issues related to changes in the content of potassium in various agricultural techniques at the biological stage of recultivation in the Far North. Agromeliorative techniques increased the accumulation of potassium in the herbage, therefore, perennial grasses consume a large amount of potassium, strengthening their ecological plasticity. It is established that agromeliorative techniques play a crucial role in providing long-term grasses with available potassium. Potassium is consumed by perennial herbs throughout life. This fact should be taken into account when determining the rates of potash fertilization to maintain a stable herbage at the biological stage of reclamation and accelerate the restoration of natural cover.
\end{abstract}

\section{Introduction}

Permafrost landscapes represent an important but complex component of the Earth's climate system. They currently cover approximately one-quarter of the land area in the Northern Hemisphere [1] and exert a major control on the local and regional hydrology and ecology [2]. The availability of plants with mineral nutrition elements from the soil depends on its absorption capacity, acid-base characteristics, and the receipt of nutrients as a result of decomposition by microorganisms [3]. The object of recultivation in the Far North is most often a biologically inert substrate of sandy or sandy loam granulometric composition with a low content of organic matter and nutrients [4]. In this regard, mineral and organic fertilizers play a decisive role in the nutrition of perennial grasses.

Potassium is one of the main elements of plant nutrition. It is consumed by perennial grasses during their growth and crop formation in large quantities. Despite the high content of total potassium in the soil, in the form available to plants, in most cases it is not enough, which makes it necessary to use potash fertilizers in all regions of the country, and especially when working to restore the soil and vegetation cover in the Far North [5].

\footnotetext{
${ }^{*}$ Corresponding author: iglovikovav@gausz.ru
} 
Numerous studies conducted in our country and abroad have established the important multifunctional role of potassium in plant life and soil fertility preservation. Along with nitrogen and phosphorus, potassium is part of the "triple alliance" of the most important biogenic elements. Also, the need to use potash fertilizers constantly drew the attention of D.N. Pryanishnikov (et al., 1941). He proposed to organize the collection of ash in the southern regions of Russia as a source of potassium for the soils of the Northern regions [6, 7].

Tundra soils are characterized by unfavorable physical and chemical properties for growing plants. This is especially true for disturbed soils whose natural soil and vegetation cover has been destroyed [8]. Also, rangelands in the United States that have been the site of military training exercises have suffered extensive ecological damage, largely because of soil compaction, creation of ruts, and damage to or destruction of vegetation-all of which lead to higher runoff and accelerated erosion [9].

Various meliorants, organic and mineral fertilizers are used to restore vegetation cover and to change the growing conditions of plants. Due to this, the physical and chemical properties of the restored soils are improved. Potassium plays an important role in plant nutrition, especially in the Far North. It increases the cold resistance of plants and makes them able to grow at low temperatures [10]. One of the goals of our research is to observe the dynamics of absorbed potassium in the application of mineral fertilizers, BIONA substrate and biomates containing peat.

\section{Materials and methods}

Field experiments to observe changes in the content of absorbed potassium at the biological stage of restoration of technogenic disturbed soils were conducted on the territory of the Yamalo-Nenets Autonomous district of the Bovanenkovskoe oil and gas condensate field (hereinafter BOGCF) and at the bottom of a 25 -year-old sand pit located $15 \mathrm{~km}$ from the city of Salekhard [11]. In experiments for perennial grasses, a nitroammophosc containing $16 \%$ nitrogen, phosphorus and potassium was introduced. Peat biomate was laid with the content of NPK-120, 140 and $180 \mathrm{mg} / \mathrm{kg}$ of soil, respectively. The basis of substrate BIONA -111 is synthetic ionites KU-2, EDE-10P. The substrate of BIONA has a $\mathrm{pH}$ close to neutral, the content of nitrogen $9 \%$, phosphorus $11 \%$, potassium $-11 \%$ calcium $0,5 \%$ [10]. The main indicators of soil composition and properties were studied using generally accepted methods. The content of absorbed potassium in the soil was studied by Chirikov. Statistical processing of the results of the study was performed using the method of B.A. Dospekhov (et al., 1985) using Microsoft Excel.

\section{Results and discussion}

Reclaimed soils of BOGCF contain relatively large reserves of total potassium (0.42$0.54 \%$ ). The main part of potassium is in the form available to plants, as evidenced by the results of its determination on control plots (Fig. 1). On average, for twelve years of research on wind-fed plots, its content in the $0.3 \mathrm{~m}$ layer was $7.6 \mathrm{mg} / \mathrm{kg}$. It is important to note that the reserves of absorbed potassium in control plots are reduced from 12.8 to 7.6 $\mathrm{mg} / \mathrm{kg}$ by the end of the growing season of perennial grasses. The minimum amount of potassium is in the $0-10 \mathrm{~cm}$ layer $-5.1 \mathrm{mg} / \mathrm{kg}$, which is due to its consumption by herbs. Down the soil profile, the amount of absorbed potassium does not change significantly (10$20 \mathrm{~cm}-9.1 \mathrm{mg}, 20-30 \mathrm{~cm}-10.2 \mathrm{mg} / \mathrm{kg}$ ).

Analysis of the obtained data shows that potash fertilizers (nitroammofoska) with a content of $16 \% \mathrm{~K} 2 \mathrm{O}$, has a positive effect on its content in the soil. Adding NPK to $90 \mathrm{~kg}$ 
of active substance/ha increases the content of absorbed potassium on average in the first three years of use of perennial herbs in the $0.3 \mathrm{~m}$ layer from 7.6 to $13.4 \mathrm{mg}(76.3 \%)$, (NPK)160 to $14.8 \mathrm{mg}(94.7 \%)$, (NPK)210 to $15.4 \mathrm{mg} / \mathrm{kg}(102.6 \%)$. There is a close direct relationship between the content of absorbed potassium and the norms of mineral fertilizers [12].

Adding potassium contributed to its significant movement deep into the soil. So, if the control plots at a depth of 20-30 cm for three years, the average potassium content was 10.2 $\mathrm{mg}$, then against the background of (NPK) 90-16.9 mg, (NPK)210-18.6 mg/kg (the average provision by Chirikov $40-80 \mathrm{mg} / \mathrm{kg}$ ). All this indicates a weak fixability of potassium fertilizers in light granulometric composition of soils [13-15].

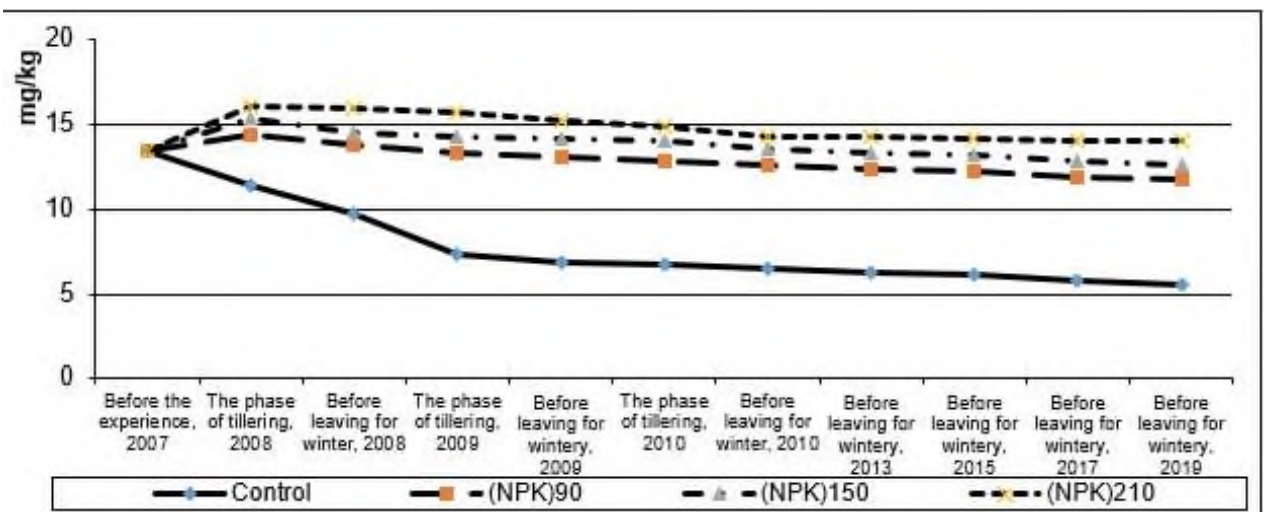

Fig. 1. Absorbed potassium content in $0.3 \mathrm{~m}$ layer when applying mineral fertilizers in the tundra zone, $\mathrm{mg} / \mathrm{kg}$ of soil.

Perennial grasses consume the maximum amount of absorbed potassium at a seeding rate of $280 \mathrm{~kg} / \mathrm{ha}$ (fig. 2). Therefore, when setting the seeding rate for reclamation grass mixtures, it is necessary to take into account not only the strengthening effect created, but also the rational use of mineral fertilizers, in part-potassium. A decrease in the potassium content at a depth of $20-30 \mathrm{~cm}$ in the variant with a seeding rate of $280 \mathrm{~kg} /$ ha indicates that the root system of herbs plays the role of a kind of biological filter, preventing the removal of mobile forms of nutrients.

Observations of changes in the content of absorbed potassium at different rates of seeding of perennial grasses, on the background (NPK)160 shows its uniform consumption.

With a seeding rate of $280 \mathrm{~kg} / \mathrm{ha}$ for the seventh year of life of perennial grasses, the content of absorbed potassium is reduced in comparison with the level of its content, before the experiment is started: at a seeding rate of $120 \mathrm{~kg} / \mathrm{ha}$ for the ninth year, and at a rate of $40 \mathrm{~kg} / \mathrm{ha}$ for the twelfth year. This fact should be taken into account when determining the feasibility of making potash feedings to maintain a stable grass stand.

Before laying the experiment to study mineral fertilizers and peat biomates in the forest tundra zone, the content of absorbed potassium in the $0.3 \mathrm{~m}$ layer was $10.8 \mathrm{mg} / \mathrm{kg}$ of soil. During the observation period, as long-term grasses grew and developed in the control plots, the number of grasses decreased almost twice (Fig. 3).

The decrease in the content of absorbed potassium occurred in the $0.3 \mathrm{~m}$ soil layer, i.e., where the bulk of the root system of perennial grasses is located. In depth, the profile of its content changed insignificantly. On the control plots, potassium migration outside the root layer was not established.

The potash regime is quite different in the case of a high dose of mineral fertilizers. Adding $160 \mathrm{~kg}$ of active substance/ha of potassium led to a significant increase in the halfmeter layer. 


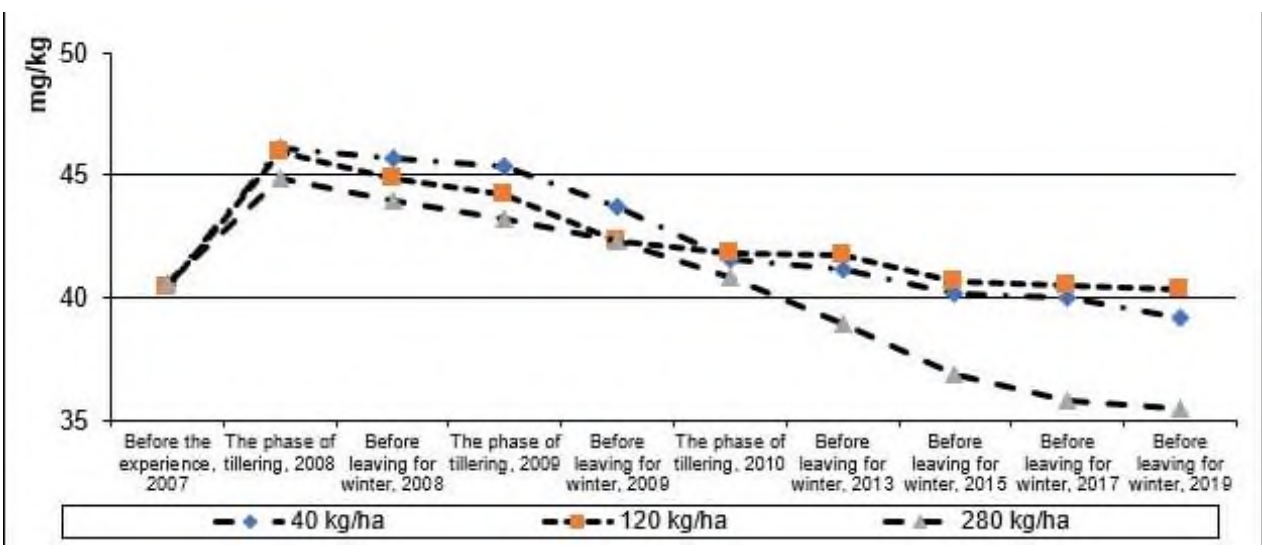

Fig. 2. Content of absorbed potassium in $0.3 \mathrm{~m}$ layer at different rates of seeding of perennial grasses in the tundra zone, $\mathrm{mg} / \mathrm{kg}$ of soil.

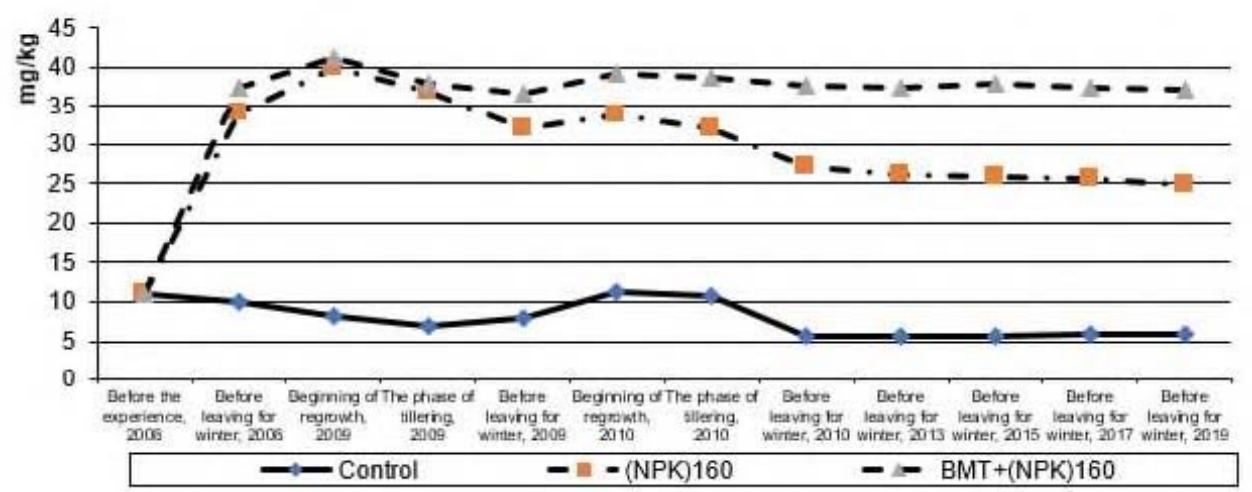

Fig. 3. Content of absorbed potassium in $0.5 \mathrm{~m}$ layer when applying mineral fertilizers and using peat biomates in the forest tundra zone, $\mathrm{mg} / \mathrm{kg}$.

On average, the amount of absorbed potassium in the $0.5 \mathrm{~m}$ layer on the background (NPK)160 was $37 \mathrm{mg} / \mathrm{kg}$ of soil during the years of research, while in the control group it was only $11 \mathrm{mg} / \mathrm{kg}$ of soil. There is an active migration of potassium outside the root zone, which is $0.3 \mathrm{~m}$. for example, the content of absorbed potassium in the layer of $0.3-0.5 \mathrm{~m}$ on the control plots was $8 \mathrm{mg} / \mathrm{kg}$ of soil. As a result of adding potassium, its amount increased to $39 \mathrm{mg} / \mathrm{kg}$ of soil, i.e. 5 times. Thus, another confirmation was obtained that potassium is weakly fixed in light granulometric composition of soils. The application of high doses of potassium leads to its unproductive losses. By the end of the twelfth year of grass life, there is a decrease in absorbed potassium reserves, especially in the root zone. At the same time, the content of absorbed potassium during all years of research on variants with its introduction does not decrease below the control.

The use of peat biomates together with mineral fertilizers further increased the content of absorbed potassium throughout the 0.5 meter layer of soil. If the average amount of absorbed potassium during the years of research was $39 \mathrm{mg} / \mathrm{kg}$ of soil when applying (NPK)160, then when using BMT in combination with fertilizers, its content increased by $14.2 \%$. The main part $(61 \%)$ of potassium is concentrated in the $0.3 \mathrm{~m}$ layer. At a depth of 0.3-0.5 m, absorbed potassium contains $41 \mathrm{mg} / \mathrm{kg}$ of soil. This is almost the same as when 
applying mineral fertilizers in pure form $(39 \mathrm{mg} / \mathrm{kg}$ of soil). Based on this fact, an important conclusion is that peat weakly fixes potassium. The main part of potassium in peat is in mobile form. Therefore, the rate of potash fertilizers should be set based on the needs of perennial grasses.

There is a close relationship between the content of absorbed potassium in the $0.3 \mathrm{~m}$ layer of soil and mineral fertilizers, peat biomates, from 0.94 to 0.97 .

The use of a BIONA substrate radically changes the situation with potassium. Thus, adding $12 \mathrm{t} / \mathrm{ha}$ of substrate increases the content of absorbed potassium in the $0.3 \mathrm{~m}$ layer from $10.8 \mathrm{mg}$ to $45 \mathrm{mg} / \mathrm{kg}$ of soil, i.e. to an average provision $(40-80 \mathrm{mg} / \mathrm{kg}$ of soil, according to Chirikov) (fig. 4).

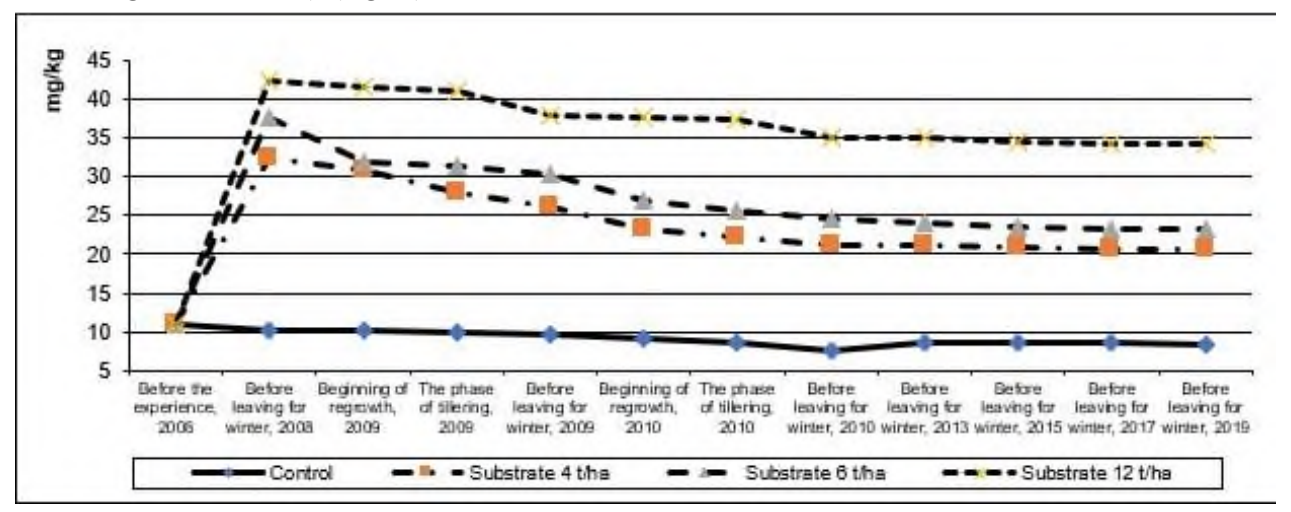

Fig. 4. The content of absorbed potassium in the $0.3 \mathrm{~m}$ layer when applying the BIONA substrate in the forest tundra zone, $\mathrm{mg} / \mathrm{kg}$.

On average, the amount of absorbed potassium in the $0-10 \mathrm{~cm}$ layer was 5 times higher compared to the control during the study period, $10-20 \mathrm{~cm}$ and $20-30 \mathrm{~cm}-4.1$ times. During all years of research, after applying $12 \mathrm{t} / \mathrm{ha}$ of BIONA substrate, the content of absorbed potassium in the $0-10 \mathrm{~cm}$ layer decreases by $15 \%, 10-20 \mathrm{~cm}$ - by $15.8 \%$, and $20-30 \mathrm{~cm}$-by $21.6 \%$. A more significant decrease in the exchange of potassium at the bottom of the $0.3 \mathrm{~m}$ layer may be due to its losses due to the light granulometric composition of the soil. The root system of perennial grasses helps to fix potassium in the $0.2 \mathrm{~m}$ layer of soil, where more than $80 \%$ of its mass is concentrated.

Table 1. Removal and utilization rates of potash from fertilizers by grass stands (average for 20172019).

\begin{tabular}{|l|c|c|}
\hline \multicolumn{1}{|c|}{ Option } & $\begin{array}{c}\text { Removal from 1 t of dry } \\
\text { weight, } \mathrm{kg}\end{array}$ & UPE from fertilizers, \% \\
\hline$(\mathrm{NPK})_{160}$ & 14.4 & 28.7 \\
\hline biomates $+(\mathrm{NPK})_{160}$ & 13.9 & 30.8 \\
\hline substrate $4 \mathrm{t} / \mathrm{ha}$ & 17.1 & 55.8 \\
\hline substrate $6 \mathrm{t} / \mathrm{ha}$ & 17.7 & 68.2 \\
\hline substrate $12 \mathrm{t} / \mathrm{ha}$ & 18.8 & 93.7 \\
\hline
\end{tabular}

A similar situation occurs in plots where the rate of the BIONA substrate was 4 and 6 $\mathrm{t} / \mathrm{ha}$. The accumulation of potassium in the lower part of the root layer indicates that the BIONA substrate should be introduced taking into account the needs of cultivated perennial grasses.

Determination of potassium removal with the harvest of perennial grasses showed that the application of mineral fertilizers up to $160 \mathrm{~kg}$ of active substance increased its removal from 1 ton of dry mass from 14.4 to $18.8 \mathrm{~kg}$, i.e. by 1.5 times. 
Under the influence of mineral fertilizers, the use of potassium by herbs increased from $28.7 \%$ (NPK) 160 to $93.7 \%$ (BION $12 \mathrm{t} / \mathrm{ha}$ ). The cost of potassium for the formation of 1 ton of dry biomass in perennial grasses was $14.4-18.8 \mathrm{~kg}$ (table. 1). An increase in the level of applied fertilizers and substrate norms led to an increase in the removal of potassium from the crop $[15,16]$.

Considering the use of potassium from fertilizers by perennial grasses, it should be noted that the high utilization factor of the power element from fertilizers of potassium from 55.8 to $93.7 \%$ was established when using the BIONA substrate in all doses of application.

Thus, when applying mineral fertilizers, using peat biomates and BIONA substrate, the removal of potassium from 1 ton of dry mass and the coefficient of its use increased. Mineral fertilizers increased the accumulation of potassium in the herbage, therefore, perennial grasses consume a large amount of potassium.

\section{Conclusions}

1.Reclaimed soils of BOGCF contain relatively large reserves of total potassium (0.42$0.54 \%$ ). The main part of potassium is in the form available to plants.

2. Adding (NPK) 90 increases the content of absorbed potassium in the $0.3 \mathrm{~m}$ layer by $76.3 \%$, (NPK) 160 - by $94.7 \%$, (NPK) 210 - by $102.6 \%$. In the following years of perennial herbs life, there is a significant decrease in the content of absorbed potassium, due to its consumption by herbs.

3.The use of a BIONA substrate at a rate of $12 \mathrm{t} / \mathrm{ha}$ increases the content of absorbed potassium in the $0.3 \mathrm{~m}$ layer from $10.8 \mathrm{mg}$ to $45 \mathrm{mg} / \mathrm{kg}$ of soil, i.e. to an average provision (40-80 $\mathrm{mg} / \mathrm{kg}$ of soil, according to Chirikov).

4. Application of mineral fertilizers up to $160 \mathrm{~kg}$ of $\mathrm{d}$. V. increased the accumulation of potassium and its removal from the crop from 14.4 to $18.8 \mathrm{~kg}$, i.e. by 1.5 times. A high potassium KPI from 55.8 to $93.7 \%$ was established when using the BIONA substrate in all application doses.

5. Agromeliorative techniques play a crucial role in providing long-term herbs with available potassium. Potassium is consumed by perennial herbs throughout life. This fact should be taken into account when determining the norms for applying potash feedings to maintain a stable grass stand at the biological stage of reclamation and accelerate the restoration of natural cover.

\section{References}

1. T. Zhang, R. Barry, K. Knowles, J. Heginbottom, J. Brown, Statistics characteristics of permafrost and ground-ice distribution in the Northern Hemisphere, Polar Geography 23, 132-154 (1999) https://doi.org/10.1080/10889379909377670

2. K.S. Aas, L. Martin, J. Nitzbon, M. Langer, J. Boike, H. Lee, T.K. Berntsen, S. Westermann, Thaw processes in ice-rich permafrost landscapes represented with laterally coupled tiles in a land surface model, The Cryosphere 13, 591-609 (2019) https://doi.org/10.5194/tc-13-591-2019

3. I.V. Sinyavsky, Recultivation of disturbed lands and development of a set of works aimed at restoring the biogeocenosis, Eurasian Scientific Association 1-7 (47), 404407 (2019)

4. A. Iglovikov, A. Motorin, Emerging technologies for recultivation of disturbed sandy soil after anthropogenic disturbances in the industrial development of the Far North, 
IOP Conference Series: Earth and Environmental Science 194(9) (2018) DOI: 10.1088/1755-1315/194/9/092009

5. A. Motorin, A. Bukin, A. Iglovikov, Water-physical properties of drained peat soils of northern Trans-Ural forest-steppe zone, IOP Conference Series: Earth and Environmental Science C. 012053 (2017)

6. G. Gamzikov, P. Barsukov, O. Varvain, The change of agrochemical properties of sodpodzolic soil during long-term use of fertilizers, Reports of the Russian Academy of agricultural Sciences 5, 28-31 (2007)

7. O. Kovaleva, N. Sannikova, Microbiological treatment system of storage ponds, Web of Conferences, The conference proceedings Innovative Technologies in Environmental Science and Education, Don State Technical University (2019)

8. A. Iglovikov, Biological recultivation of quarries in the Far North. Abstract of the dissertation for the degree of candidate of agricultural Sciences. Altai state agrarian University (Barnaul, 2012)

9. P. Bradford, W. Wilcox, L. Fox, et.al. Contour ripping is more beneficial than composted manure for restoring degraded rangelands in Central Texas, J. Environ. Manage. 111, 87-95 (2012)

10. A. Iglovikov, A. Motorin, Of optimizing the phosphate regime of drained peat soils in the northern trans-urals. E3S Web of Conferences. The conference proceedings Innovative Technologies in Environmental Science and Education. Don State Technical University (2019)

11. A. Iglovikov, A. Motorin, Development of artificially created phytocenosis at the biological stage of reclamation in the conditions of the Far North, Siberian Bulletin of agricultural science 6 (247), 50-56 (2016)

12. D. Eremin, Soils swelling as a regional feature of Western Siberia. MATEC Web of Conferences (2018) DOI: 10.1051/matecconf/201817002017

13. S. Germanova, T. Dryomova, N. Sambros, N. Petukhov, P. Petrovskaya, Innovative methods for remediation of contaminated soils. Modern science: actual problems of theory and practice, Series: Natural and technical Sciences 3, 10-12 (2019)

14. D. Eremin, D. Eremina, Influence of granulometric composition, structure of anthropogenic-reformed on soil ecology of infrastructure, Procedia Engineering 165, 788-793 (2016) DOI: 10.1016/j. proeng. 2016.11 .776

15. A. Iglovikov, The development of artificial Phytocenosis in Environmental Construction in the far North, Procedia Engineering 165, 800-805 (2016) DOI: 10.1016/j.proeng.2016.11.778

16. A. Tikhanovsky, Theory and practice of application of fertilizers on soils of the Far North (M: publishing house "Scientific consultant", 2015) 